\section{EL MERCADO DE LA OBRA DE ARTE: Concienciación Cultural y Conservación}

El nexo entre mercado y cultura se nos revela en toda su importancia apenas observamos la evolución que ha sufrido el mercado y la cultura en los últimos veinte años. En los años setenta y ochenta se ha manifestado el inicio de nuevas e inmensas fortunas personales en el ámbito de los países desarrollados, que han modificado los mercados el arte y orientado las políticas públicas. Parece que nos encaminamos hacía la conclusión de un ciclo en el curso del cual las reglas de la eficiencia, de la competitividad y del provecho, han influido en sentido único el comportamiento de los artistas, de los marchantes y de los políticos.

Como afirma el Señor Lord Gowrie presidente de la Southeby's Europa "La llegada de una nueva riqueza es el motor que empuja a coleccionar arte en nueve casos sobre diez".

Dado que el arte es de entre todas las manifestaciones creativas, música pop aparte, la forma más internacionalmente accesible, todos los estados que en los años ochenta atravesaban por un período económicamente fructífero, han asistido a un excepcional crecimiento de intereses artísticos por parte del público. Este hecho ha dado como consecuencia que las imágenes del arte que han dominado la escena internacional oscilan entre los extremos de la inversión cultural y de la diversión de masas.

El valor simbólico de una obra de arte se ha ido identificando con su valor de mercado. Dinero y recreación se han convertido en los falsos objetivos de las políticas públicas que han descuidado otros aspectos estructurales y culturales de interés, como la educación de los consumidores en materia de Arte.

Entre los principales fenómenos que nos ayudan a comprender este estado de cosas destaco como más significativos los siguientes:

- En primer lugar, "La Economía de Tiempo", el aumento del bienestar hace del tiempo libre un bien cada vez más caro. Analizando este fenómeno, la contradicción en la cual cae la sociedad rica que tiene los medios para mejorar el consumo cultural, cada vez dispone de menos tiempo libre para su disfrute. De tal forma, que no llega a encontrar una tarde o una noche para dedicarla a la lectura, para asistir a una obra teatral, o para visitar un Museo o una galería de arte.

Frente a la nueva necesidad de ahorrar tiempo, la respuesta de la tecnología ha sido rápida y destructora. La televisión, el desarrollo de la fotografía de calidad y la reproducción sonora y de imágenes de alta fidelidad han suministrado a millones de familias los objetos coleccionables, desde el compact disk, o el video-casset, hasta los actuales ambientes virtuales que nos permiten asistir "desde la realidad y desde dentro" a un acontecimiento cultural permaneciendo cómodamente en casa, transformando formas de espectáculos y de arte, que en un tiempo fueron de élite, en fenómenos de masas. Buscando satisfacer al máximo número de consumidores se cae en el eclectismo y desciende la calidad.

- La segunda transformación está relacionada con la explosión de los mercados de bienes de colección. En una sociedad como la nuestra, rica y opulenta, cada uno de nosotros quisiera ser un pequeño mecenas, poseer algo precioso, reconocido por la cultura dominante como "unicum" e irrepetible o, simplemente, algo que pertenece al pasado o a la tradición.

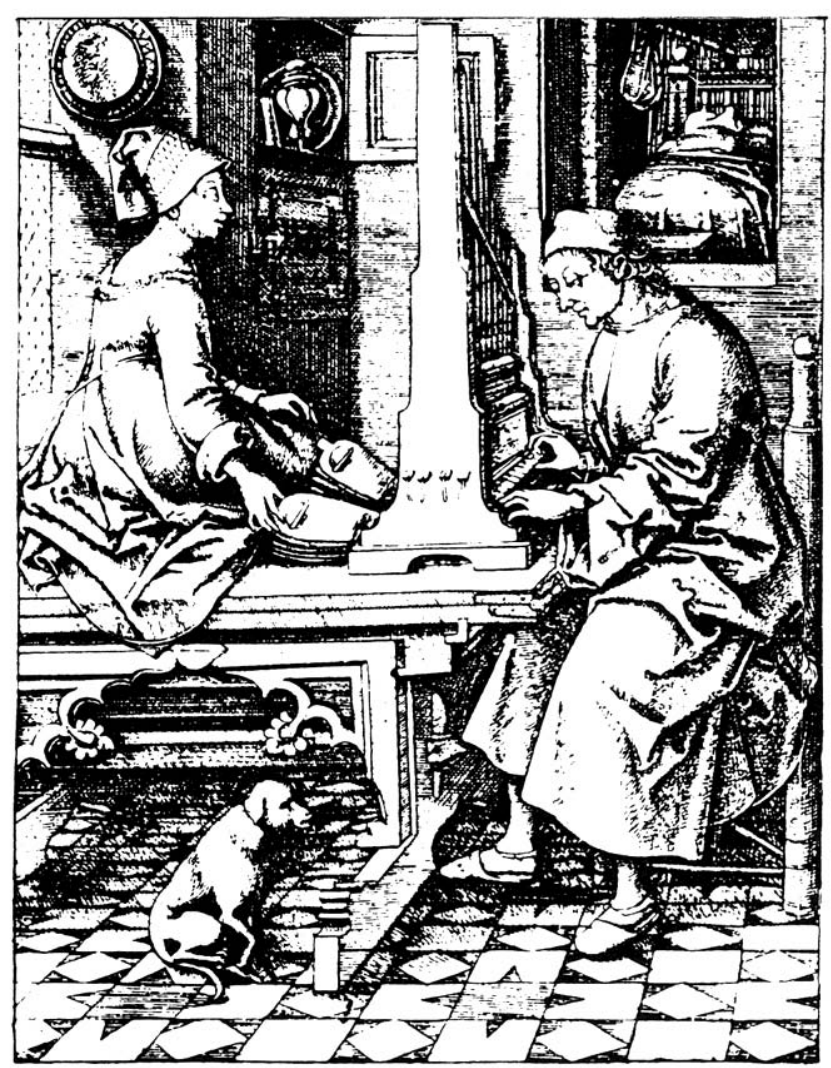

Cuando los grandes hombres de negocios captaron la potencialidad económica de los mercados del coleccionismo se produce la confusión. El valor económico domina sobre el valor simbólico. Los grandes capitales van a la caza de obras cada vez más raras. Los precios se disparan a las estrellas y ciertos mercados elitistas cortejan a los pocos artistas consagrados, transformando la obra de arte en un bien capital, móvil, y líquido.

La presencia del estado es en este "marco", objeto de instrumentalización mercantil, por ejemplo una obra de propiedad privada es expuesta en un Museo público para ser valorizada, o un artista es consagrado en una exposición organizada por un Ente o Institución Pública.

- El tercer cambio que se produce en los últimos veinte años, está directamente relacionado con la lógica que aplica la intervención pública.

El Estado se transforma de protector del Patrimonio, a veces severo, emprendedor cultural. Valorizar y dinamizar son los términos de moda, sustituyéndose en gran parte el concepto de conservación de un bien cultural por el de su disfrute, que permite al mismo tiempo que atraer a grandes masas de visitantes, el desarrollo turístico, el crecimiento de la ocupación y de la renta local.

Todavía, como justamente subraya el profesor Moschini en Memorabilia, se necesita distinguir entre "cultura de masas", que todavía resulta una utopía, y "el consumo cultural de masas", que es por el contrario un aspecto característico de nuestro tiempo. En efecto, mientras que el aumento de las personas que conocen y disfrutan de los bienes culturales, es indudablemente un hecho positivo de la sociedad actual, además de una conquista democrática, el consumo cultural no es sólo una ulterior fuente de degradación del Patrimonio Artístico, sino también es culturalmente negativo porque comporta a la recepción pasiva de las 
informaciones suministradas por los "mas media" sobre cuestiones, como la calidad de una obra de arte, o de una restauración, que deberían requerir un juicio libre, personal y posiblemente documentado. Obteniéndose a menudo un proceso educativo a la inversa, que en vez de conseguir elevar el nivel cultural del público desciende el nivel del mensaje.

Frente al enorme aflujo de público que se produce en algunas exposiciones temporales conviene interrogarse, cuántos visitantes han sido motivados por un genuino interés cultural y cuantos, por el contrario, se han sentido atraídos sólo por la resonancia del acontecimiento de moda difundido por los medios de comunicación.

Se necesita por tanto analizar atentamente las razones del incremento de intereses en torno a los bienes culturales, aunque sólo sea por intentar, en lo posible, poner límites a algunos aspectos aberrantes.

En el aumento de la demanda de cultura que caracteriza a la sociedad de los últimos 15 años, hay que analizar y distinguir si este crecimiento se debe a una necesidad genuina $\mathrm{o}$, por el contrario, es inducido por la oferta de mercado.

Es este por ejemplo el caso de la oferta masificada de pseudo-cultura que ha caracterizado la política de muchas administraciones públicas en los últimos veinte años.

Esta evolución ha cambiado profundamente la consideración en sí misma de los bienes culturales, porque como afirma el profesor Benjamín: "La Obra de Arte parece destinada a asumir funciones completamente nuevas entre las cuales, aquella de la cual somos consciente, es decir la artística, se perfila como aquella que, en un futuro, podrá ser considerada marginal".

- Otro aspecto que se considera importante analizar es cómo una de las variables que pueden influir de forma determinante en el valor de una obra de arte, es sin duda el estado de conservación que presenta.

Una obra íntegra, es decir perfecta, tiene un mercado más amplio. Los Museos, sobre todos los americanos, raramente toman en consideración la adquisición de obras restauradas en profundidad, aún cuando éstas hayan sido sabiamente intervenidas.

También los coleccionistas privados se desaniman cuando la obra presenta amplias intervenciones de restauración, de tal forma que en el momento de su adquisición pueden modificar su precio real por otro excepcionalmente conveniente.

Estos factores conllevan a establecer un debate en el ámbito de la Historia del Arte sobre los límites de intervención en la restauración. En particular, en aquellos casos en los que las intervenciones realizadas sobre un objeto artístico se han vuelto históricas, conviene demandarse si deben ser eliminadas para devolver a la obra su estado original o, si por el contrario, conviene salvaguardarlas como testimonio de su historia externa.

Este debate tuvo un memorable desarrollo en los años setenta cuando se discutió las intervenciones masivas que se venían efectuando sobre monumentos o sobre bienes culturales, en la mayoría de los casos, desnaturalizándolos o reinterpretándolos. Fruto de este debate es el documento titulado "La carta del restauro de Venecia, 1972" al cual se dio una particular difusión, como indicador de las líneas de intervención a privilegiar, salvo casos particulares.

En 1971 en Italia se publica una Ley llamada "Pieraccini" por el nombre de su autor (20 de noviembre de 1971, n. ${ }^{\circ} 1.062$ ) que penaliza como falsificador a aquellas personas que pongan a la venta obras de arte en las cuales la restauración haya reconstruido de forma determinante el original, con independencia de si la intervención es reciente o antigua.

De todo esto se deriva que lo importante es la desnaturalización del original. Por tanto el vendedor, debe señalar adecuadamente la restauración, aún cuando ésta sea de época remota siempre y cuando él sea consciente.

Llegados a este punto conviene preguntarse ¿Cuándo la restauración convierte un original en falso?

Para responder a esta pregunta considero necesario recurrir a una noción histórico-artística, propugnada por Alessandro Gotlieb Baumgartner, elaborada para la pintura, pero válida también, desde mi punto de vista, para otras artes creativas: "La trama pictórica".

El arte es palabra, lenguaje en cada una de sus manifestaciones. Pertenece a un momento de conocimiento pre-lógico, en el cual el significado de la obra de arte se reduce a idea, si no a concepto. En cada manifestación artística la esencia cognoscitiva se expresa a través de diversos medios.

El lenguaje de la pintura es la "trama pictórica", o sea aquella interrelación expresiva de luces y sombras, de dibujo y color, de planos, de imaginación, que constituyen el "tejido" complejo de la obra, su valor ideal, su aura poética.

Incidir sobre la "trama pictórica" significa desnaturalizar la obra de arte, como introducir notas disonantes en música melódica, o notas asonantes en música dodecafónica.

En época relativamente reciente se ha producido un cambio en la convicción de que no es posible realizar una valoración crítico-estética de la creación artística, cuando ésta última se presente alterada, en su totalidad o en parte, a causa de sucesivas transformaciones o reparaciones debidas a las manos de restauradores.

Se deriva la necesidad de perfeccionar los criterios teóricos y las técnicas cognoscitivas con objeto de alcanzar una lectura siempre más nítida del original, ya sea en el caso de remover reintegraciones, o de tratar eventuales lagunas de un modo u otro.

Pero las técnicas tradicionales de conservación y de restauración han continuado y continúan rescatando la confianza universal, hasta el punto de ser consideradas adecuadas para resolver cualquier exigencia conservativa. Como si estas exigencias fuesen todas del mismo tipo y no tuvieran características propias, que nacen de la constitución física y de las particulares condiciones de vida de cada obra de arte.

El conocimiento de estas características con medios y criterios científicos rigurosamente precisos debería ser, por el contrario, la base de cualquier acto conservativo, como premisa a la diagnosis de los males que afectan a la obra y a la consecuente selección de los métodos de intervención más idóneos.

El conocimiento de una obra de arte se ha realizado en el pasado principalmente a través de una aproximación de naturaleza histórico-artística. Las intervenciones sobre una obra con intención de restaurarla o conservarla han estado tradicionalmente basadas sobre criterios tecnológicos más o menos empíricos. 